\title{
Phytochemical Analysis of Nigella sativa L. Utilizing GC-MS Exploring its Antimicrobial Effects against Multidrug-Resistant Bacteria
}

\author{
Fatima A. Saleh', Nada El-Darra², Karim Raafat ${ }^{3, *}$, Iman El Ghazzawi ${ }^{1}$
}

\section{Fatima A. Saleh ${ }^{1}$, Nada El-Darra ${ }^{2}$, Karim Raafat ${ }^{3, *}$, Iman El Ghazzawi ${ }^{1}$}

'Department of Medical Laboratory Sciences, Faculty of Health Sciences, Beirut Arab University, LEBANON. ${ }^{2}$ Department of Nutrition and Dietetics, Faculty of Health Sciences, Beirut Arab University, LEBANON.

${ }^{3}$ Department of Pharmaceutical Sciences, Faculty of Pharmacy, Beirut Arab University, LEBANON.

\section{Correspondence}

\section{Karim Raafat}

Pharmaceutical Sciences Department, Faculty of Pharmacy, Beirut Arab University (BAU), 115020 Beirut, LEBANON.

Tel.:+961 1300110;

Fax: +961 1300110 Ext:2599

E-mail: k.raafat@bau.edu.lb, karim.raafat@yahoo.com

\section{History}

- Submission Date: 22-09-2017;

- Review completed: 18-10-2017;

- Accepted Date: 02-11-2017

DOI : 10.5530/pj.2018.1.18

Article Available online

http://www.phcogj.com/v10/i1

\section{Copyright}

(C) 2018 Phcog.Net. This is an openaccess article distributed under the terms of the Creative Commons Attribution 4.0 International license.

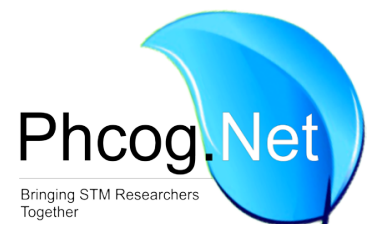

\begin{abstract}
Introduction: The alarming increase in bacterial strains resistant to existing antimicrobial agents has demanded alternative strategies. Medicinal plants are now considered as an alternative treatment because of their secure choice in several diseases. Among them, NigeIla sativa is a promising traditional herb having rich medical background. The aim of the study is to perform phytochemical analysis of Nigella sativa L. Utilizing Gas chromatographic-mass spectrometric (GC/MS) exploring its antioxidant and antibacterial activity against multidrug resistant (MDR) gram-positive and gram-negative bacteria. Methods: Total phenolic, tannin, and flavonoid content of $N$. sativa seed extracts and its commercially available oil were determined. Their radical scavenging activity using DPPH was also tested. The antibacterial activity of $N$. sativa seed extracts and its oil against MDR gram-positive and gram-negative bacterial strains was studied using disc diffusion test and the biofilm formation assay. GC-MS studies were also performed. Results: Among the different preparations used, N. sativa oil showed the highest antioxidant and antibacterial activity against highly resistant gram-positive bacteria with the greatest suppression of biofilm formation, which was attributed to its high bioactive contents. Conclusion: This study indicates that $N$. sativa extracts and its oils can be used as natural antibacterial agents to treat infections caused by multidrug resistant bacteria.
\end{abstract}

Key words: Nigella sativa, Antibacterial, Antioxidant, GC-MS analysis, Multidrug resistant bacteria.

\section{INTRODUCTION}

Since the discovery of penicillin, the world's first antibiotic, there was the medical belief that this development will lead to the eradication of infectious diseases. However, the overuse and misuse of these antibiotics have led to the emergence of multidrug-resistant bacteria. Recently, antibiotic resistance has reached a dramatic low-point that some infections have developed resistance to even vancomycin, which is considered as the 'antibiotic of last resort.' ${ }^{1}$ Therefore, this has initiated an interest towards the development of alternative antibacterial agents and the re-evaluation of the therapeutic uses of herbal extracts and essential oils. ${ }^{2}$ Herbal extracts and their essential oils are rich in phytochemicals, such as phenolics, flavonoids and tannins, ${ }^{3}$ which are sources of natural antioxidants and provide protection against predation by microbial pathogens. ${ }^{4}$ Besides, a large number of studies have found a good correlation between the phytochemical content and the antimicrobial efficacy of the herbs investigated, indicating that these secondary metabolites are responsible for the antimicrobial effect. ${ }^{5}$ Among them, Nigella sativa (N. sativa) belonging to the Ranunculaceae family is a promising herb, often referred to as the nature's miracle remedy. ${ }^{6}$
$N$. sativa, also known as black cumin, grows in many countries around the Mediterranean Sea.? Seeds of $N$. sativa have been used as a condiment in the food industry and as a traditional remedy for a number of diseases including asthma, hypertension, diabetes, eczema, inflammation, rheumatism, jaundice and gastrointestinal problems. ${ }^{8}$ In recent years, both seeds and its oil have been widely investigated and reported to exhibit several pharmacological effects such as analgesic, anti-inflammatory ${ }^{9}$ anticancer ${ }^{10}$ antiulcer ${ }^{11}$ and antibacterial activity. ${ }^{12}$ Ugur et al. ${ }^{13}$ making their treatment difficult. Nigella sativa oil is known to be active against Gram-positive cocci, yet its in vitro cytotoxicity is rarely investigated, is a proper and powerful candidate for treatment of methicillin-resistant isolates. OBJECTIVES:: The aim of this study is to evaluate the in vitro antibacterial activity and cytotoxicity effect of N. sativa oil. MATERIALS AND METHODS: The minimal inhibitory concentrations (MICs) showed that N. sativa oil has an excellent antibacterial activity against clinical isolates of methicillin-resistant $S$. aureus and methicillin-resistant coagulase-negative Staphylococci with very low MIC range of $<0.25-1.0 \mu \mathrm{g} / \mathrm{ml} .{ }^{13}$ Other

Cite this article: Saleh FA, El-Darra N, Raafat K, Ghazzawi IEL. Phytochemical analysis of Nigella sativa L. Utilizing GC-MS exploring its antimicrobial effects against multidrug-resistant bacteria. Pharmacog J. 2018;10(1):99-105. 
studies reported that $N$. sativa seed oil is rich in phenolic compounds with strong antioxidant properties. ${ }^{14}$ The phytochemical composition of $N$. sativa oil was further characterized by many studies. Farag et al. showed that $N$. sativa oil contains more than 52 Metabolites including 8 saponins, 10 flavonoids, 6 phenolics, 10 alkaloids, and 18 fatty acids that might be utilized for their health benefits. ${ }^{15}$

The present study was conducted to determine total phenolic, tannin, and flavonoid content of $N$. sativa seed extracts and its commercially available oil and to carry gas chromatographic-mass spectrometric studies to describe the essential oil and fixed oil (fatty acid) composition of the different $N$. sativa preparations. Their antiradical activity using DPPH method and the antibacterial activity against multidrug resistant strains were also performed.

Therefore, the aim of the current study was to perform phytochemical analysis of Nigella sativa L. utilizing GC-MS exploring its antioxidant and antibacterial activity against multidrug resistant (MDR) gram-positive and gram-negative bacteria.

\section{MATERIALS AND METHODS}

\section{Nigella sativa preparation}

$N$. sativa seeds (imported from India) were purchased from a local herb store in Beirut, Lebanon. Seeds were identified and authenticated with reference sample and were given voucher specimen number (NS-16-14) and stored in the Faculty herbarium. The seeds were grounded to a powder shape using an electric grinder for $5 \mathrm{~min}$, and then the grounded samples $(50 \mathrm{~g})$ were soaked overnight in $200 \mathrm{ml}$ of distilled water or methanol under shaking for the preparation of aqueous and methanolic extracts, respectively. The extracts were then centrifuged, filtered twice then filter sterilized using nitrocellulose membrane filter. Sterile-filtered oil and capsules oily content of N. sativa (Pharco Pharmaceuticals, Egypt) were included in this study.

\section{Bacterial strains, culture media and growth conditions}

Eleven multiple antibiotic resistant bacterial strains were included in this study. They are clinical isolates provided by the Faculty of medicine, Alexandria University, Egypt. The isolates tested include the following gram-positive strains: 2 Methicillin-resistant Staphylococcus aureus (MRSA), 2 Methicillin-resistant Staphylococcus epidermidis (MRSE), high-level aminoglycoside-resistant (HLAR) Enterococci (Enterococcus faecalis and Enterococcus faecium which was also vancomycin- resistant (VRE)). Furthermore, the following gram-negative strains including 1 strain of Pseudomonas aeruginosa, 2 strains of Klebsiella pneumoniae and 2 strains Acinetobacter baumannii were also studied. The strains of Klebsiella pneumoniae and Acinetobacter baumannii were previously proved to be extended-spectrum $\beta$-lactamases (ESBL) as well as Carbapenemase producers. All strains were previously validated at the Microbiology laboratory, Faculty of Medicine, Alexandria University, Egypt. MRSA and MRSE by doing cefoxitin sensitivity test, HLA enterococci by using gentamicin discs and Vancomycin resistant enterococci by vancomycin sensitivity test. All gram-negative strains were identified by different biochemical reactions. The ESBL strains were identified by double synergy test while Carbapenemase production by modified Hodge tests.

\section{Total Phenolic Content determination}

The total phenolic content was determined according to FolinCiocalteu (FC) method. ${ }^{16} 0.2 \mathrm{ml}$ of standard (gallic acid) or diluted sample, $1.0 \mathrm{ml}$ of FC reagent, and $0.8 \mathrm{ml}$ of $\mathrm{Na}_{2} \mathrm{CO}_{3}$ solution (7.5\%) were mixed and allowed to stand for $2 \mathrm{~h}$ at room temperature. Light absorption was measured at $750 \mathrm{~nm}$ by a spectrophotometer UV-VIS against a blank similarly prepared, but containing distilled water instead of extract. The total phenolic content $(\mathrm{Ye}$ ) was expressed in $\mathrm{mg} / \mathrm{ml}$.

\section{Determination of tannin concentration}

Total tannin content (g/l) was determined according to Ribérau-Gayonand collaborators. ${ }^{17}$ Total tannin assay is based on the heating process of tannins in acidic medium leading to the formation of cyanidins. Two tubes were prepared, each containing $1 \mathrm{ml}$ of the sample, $0.5 \mathrm{ml}$ of water and $1.5 \mathrm{ml}$ of $12 \mathrm{~N} \mathrm{HCl}$. The first tube was mixed and heated in a water bath at $100^{\circ} \mathrm{C}$ for $30 \mathrm{~min}$. The second was kept at room temperature. Following the rapid cooling, $0.25 \mathrm{ml}$ of ethanol was added to the mixture and the resulting absorbance was recorded at $520 \mathrm{~nm}$.

\section{Free radical scavenging activity}

The DPPH (1,1-diphenyl-2-picrylhydrazyl) radical was used in the present study for the screening of the radical scavenging activity of the extracts. ${ }^{18}$ The DPPH radical scavenging activity was measured using the spectrophotometer UV-VIS (Libra S32, Biochrom, France). The samples were tested at a concentration of $20 \mathrm{mg} / \mathrm{ml}$ then mixed with $1000 \mu \mathrm{l}$ of $0.1 \mathrm{mMDPPH}$-ethanol solution and $450 \mu \mathrm{l}$ of $50 \mathrm{mM}$ Tris- $\mathrm{HCl}$ buffer $(\mathrm{pH}$ 7.4). Methanol $(50 \mu \mathrm{l})$ was used for blank measurements in this experiment. After $30 \mathrm{~min}$ of incubation at room temperature, the reduction of the DPPH free radical was measured by reading the absorbance at $517 \mathrm{~nm}$. Butylhydroxytoluene (BHT) (a synthetic antioxidant) was used as a positive control. The inhibition ratio (percent) was calculated according to the following equation:

$$
\% \text { inhibition }=\left[\begin{array}{l}
(\text { absorbance of control }- \\
\text { absorbance of test sample })
\end{array}\right] \times 100
$$

\section{Determination of total flavonoids (TF)}

The total flavonoids (TF) assay was done aspreviously described by Zhuang and coworkers ${ }^{19}$ after bringingminor modifications. A volume of $1 \mathrm{ml}$ of diluted extract or standard solution of catechin was placedin a $10 \mathrm{ml}$ volumetric flask already containing $4 \mathrm{ml}$ of $\mathrm{H}_{2} \mathrm{O}$. Five minutes later, $0.3 \mathrm{ml}$ of $\mathrm{NaNO}_{2}(5 \%)$ and $1.5 \mathrm{ml}$ of $\mathrm{AlCl}_{3}(2 \%)$ were added. The mixture was shaken for $5 \mathrm{~min}$ then $2 \mathrm{ml}$ of $1 \mathrm{M}$ solution of $\mathrm{NaOH}$ were added and the mixture was well shaken again. The absorbance was measured at $510 \mathrm{~nm}$ against the blank. The results were calculated according to the calibration curve for catechin $\left(\mathrm{R}^{2}=0.99\right)$. The content of TF was expressed as $\mathrm{mg}$ of catechin equivalent (CE) per $1 \mathrm{~g}$ of dry matter content. All samples were analyzed in duplicate.

\section{Disc diffusion test}

For the preparation of bacterial suspension of each strain to be tested, 5 colonies were picked from fresh blood agar culture and inoculated onto $3 \mathrm{ml}$ saline then left for 5 minutes. Each strain suspension was swabbed onto plates of Muller Hinton agar and $5 \mathrm{~mm}$ sterile filter paper discs were placed on top. Aqueous extract, Methanolic extracts (undiluted, diluted 1:1), Oil (crude, diluted 1:1 in ethylene glycol (EG) and diluted 1:1 in dimethyl sulfoxide (DMSO) and capsule content were tested for their inhibition effect on the strains. This was performed by pipetting $5 \mu \mathrm{l}$ of all preparations on $5 \mathrm{~mm}$ sterile discs. Negative controls were included. After overnight incubation, the inhibition zones were recorded. ${ }^{20}$

\section{Biofilm formation}

An overnight broth culture of each bacterial strain (2 MRSA, 1 MRSE) tested were diluted 1:5 in tryptic soya broth. For each bacterial strain, fivesterile beakers containing a $2.5 \mathrm{~cm}$ coverslip were used, where $300 \mu \mathrm{l}$ bacterial suspension was added. An equal volume of methanolic extract, crude oil, oil diluted in EG and capsule content, was added to each beaker, leaving one untreated to serve as a positive control. All beakers were incubated overnight at $37^{\circ} \mathrm{C}$. Then, each beaker was washed $3 \mathrm{x}$ with distilled water, fixed with $95 \%$ of ethanol for $30 \mathrm{~min}$ and stained with 
$0.1 \%$ crystal violet for an hour. After a final wash, the coverslips were air-dried and microscopically visualized for biofilm formation. ${ }^{21}$

\section{GC-MS Analysis}

The GC-MS investigation of the Nigella sativa oil, capsule, methanolic and aqueous extracts have been made in an Agilent instrument (Agilent, Japan) under computer control at $70 \mathrm{eV}$. About $1 \mu \mathrm{l}$ of each sample was injected into the GC-MS and the scanning has been done for $25 \mathrm{~min}$. The oven temperature has been maintained at $100^{\circ} \mathrm{C}$. Helium gas has been utilized as carrier and eluent. The helium flow rate has been set at $1 \mathrm{ml} / \mathrm{min}$. HP-5MS capillary-column $(30 \mathrm{~m} \times 0.25 \mathrm{~mm} ; 0.25 \mu \mathrm{m}$ film-thickness) has been utilized as the GC-column for components separation. The identity and quantifying of the oil components have been assigned by the comparison of their retention indices and mass spectra fragmentation patterns with those stored on the computer library and the reference standards calibration curves. ${ }^{22}$

\section{Statistical analysis}

The result are expressed as mean \pm SD. Analysis of variance (ANOVA) was used to test for differences in the groups and multiple range test of significance was used.

\section{RESULTS AND DISCUSSION}

\section{Polyphenol, tannins and flavonoids content of different N. sativa} preparations

Figure 1 shows that the highest concentration of total phenolic compounds and flavonoids were found in the capsules and oil followed by the methanolic and aqueous extracts. The amount of polyphenols in oil and capsules $(248 \mathrm{mg} / \mathrm{ml})$ was higher than the one found in seeds extracts (21 $\mathrm{mg} / \mathrm{ml}$ for the aqueous extract and $39 \mathrm{mg} / \mathrm{ml}$ for the methanolic extract).Similar results were obtained for the flavonoids with a concentration of $19.8 \mathrm{mg} / \mathrm{ml}$ for the oil and capsules followed by the methanolic $(2.98 \mathrm{mg} / \mathrm{ml})$ and the aqueous extract $(0.11 \mathrm{mg} / \mathrm{ml})$. However, for the tannins, the highest amount $(8.3 \mathrm{mg} / \mathrm{ml})$ was noted for the capsules, followed by the oil $(3.4 \mathrm{mg} / \mathrm{ml})$, and methanolic extract $(1.5 \mathrm{mg} / \mathrm{ml})$ while the aqueous extract contains only $0.49 \mathrm{mg} / \mathrm{ml}$. These results are in accordance with a study by Cheikh-Rouhou et al., $2007^{23}$ which showed that $N$. sativa oil is a potential source of natural phenolic compounds.

\section{Antiradical activity of $N$. sativa Extracts against DPPH radical}

The assessment of the antiradical activity of the aqueous and methanolic extracts, oil and capsules was also performed (Figure 2). DPPH is a stable radical, widely used to evaluate the free radical scavenging activity in many plant extracts. ${ }^{24}$ The assessment of antiradical activity showed that all $N$. sativa preparations were able to scavenge this radical. Oil and capsules displayed a higher activity, $16 \%$ and $17 \%$ inhibition of the radical, respectively. Whereas, methanolic and aqueous extracts exhibited a lower antiradical activity (12\% and $7 \%)$. The high antiradical activity of the oil and capsules could be mainly attributed to their high phenolic content that act as a free radical scavenger. ${ }^{25}$ found that antiradical activity of $N$. sativa extracts increased proportionally to the polyphenol content with a linear relationship between radical inhibition and total polyphenols. Similar studies by ${ }^{26,27,28}$ showed concentration-dependent radical scavenging activity of polyphenol extracts.

\section{Antibacterial activity of Nigella sativa preparations}

The aqueous extract, methanolic extracts (undiluted, diluted 1:1), oil extracts (crude oil, oil in ethylene glycol 1:1, oil in DMSO 1:1) and capsule content of different $N$. sativa samples were evaluated for their antibacterial activities against different resistant gram-positive and gramnegative bacterial strains using the disc diffusion method by measuring the inhibition zone (Table 1). As shown in Table 1 the aqueous extract did not exhibit any antibacterial activity. However, the other preparations

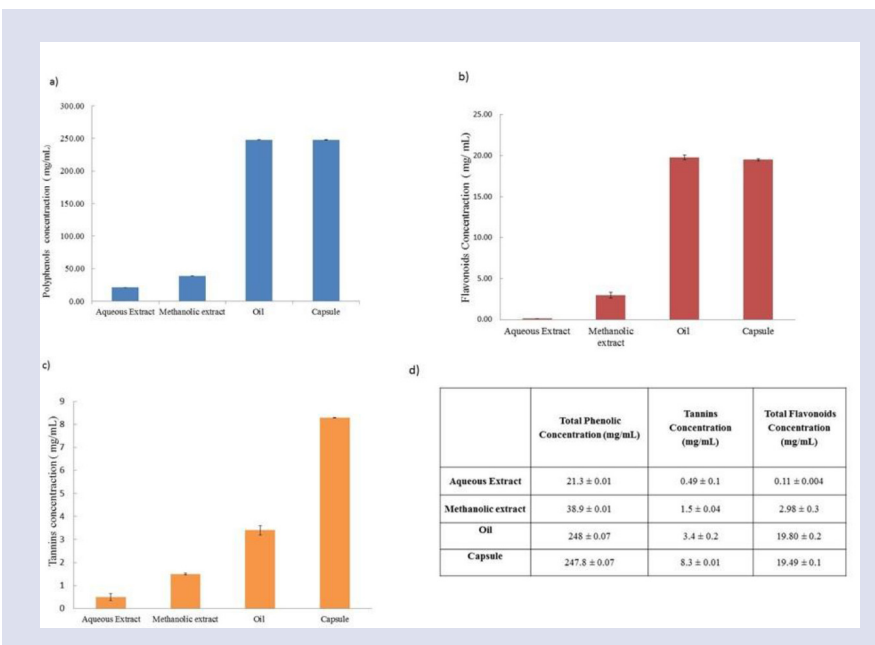

Figure 1: Amount of total phenolic compounds (a), total flavonoids (b) and tannins (c) of the different Nigella sativa preparations (aqueous extract, methanolic extract, oil and capsules). The results are given as means \pm SD of three measurements (d).

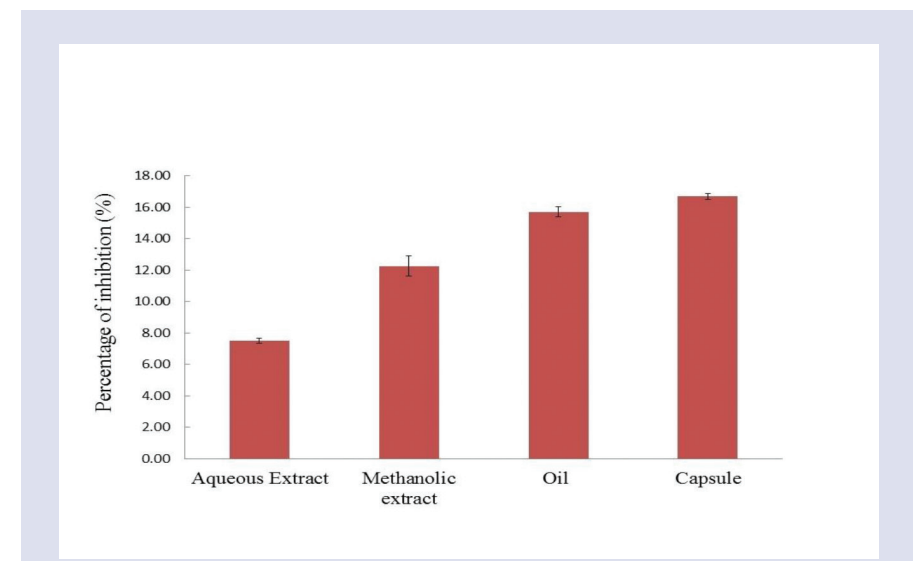

Figure 2: Radical scavenging capacity of Nigella sativa preparations (aqueous, methanolic, oil and capsules) against DPPH radical.

showed antibacterial activities with different efficacy. These results are in agreement with a study by, ${ }^{29}$ which reported lower antibacterial activity for the aqueous extract of high phenolic content plant like rosemary compared to its methanolic extract. The inhibitory effect for the different extracts is higher for the gram-positive strains than for the gram-negative strains. Our findings are in concordance with the findings of ${ }^{30}$ which showed that phenolic compounds have enhanced activity against gram-positive strains compared to gram-negative, due to the presence of an outer membrane in the cell wall of the latter, thus acting as permeability barrier and reducing the uptake of polyphenols. ${ }^{31}$ The capsules showed the highest inhibitory activity against the different tested gram-positive strains. The extracts in pure methanol showed inhibitory activity against the different tested gram-positive and gram-negative strains. Other extracts (diluted methanol, oils (crude and diluted)) were found to be active against all the tested species of gram-positive bacteria whereas the gram-negative bacteria remained unaffected. Our results are in accordance with the study by, ${ }^{32}$ that showed that methanolic extracts were more effective against both gram-positive and gram-negative bacteria tested, which could be explained by a better extraction of 
Table 1: Inhibition zone of the different Nigella sativa preparations against different bacterial strains (gram + and gram -)

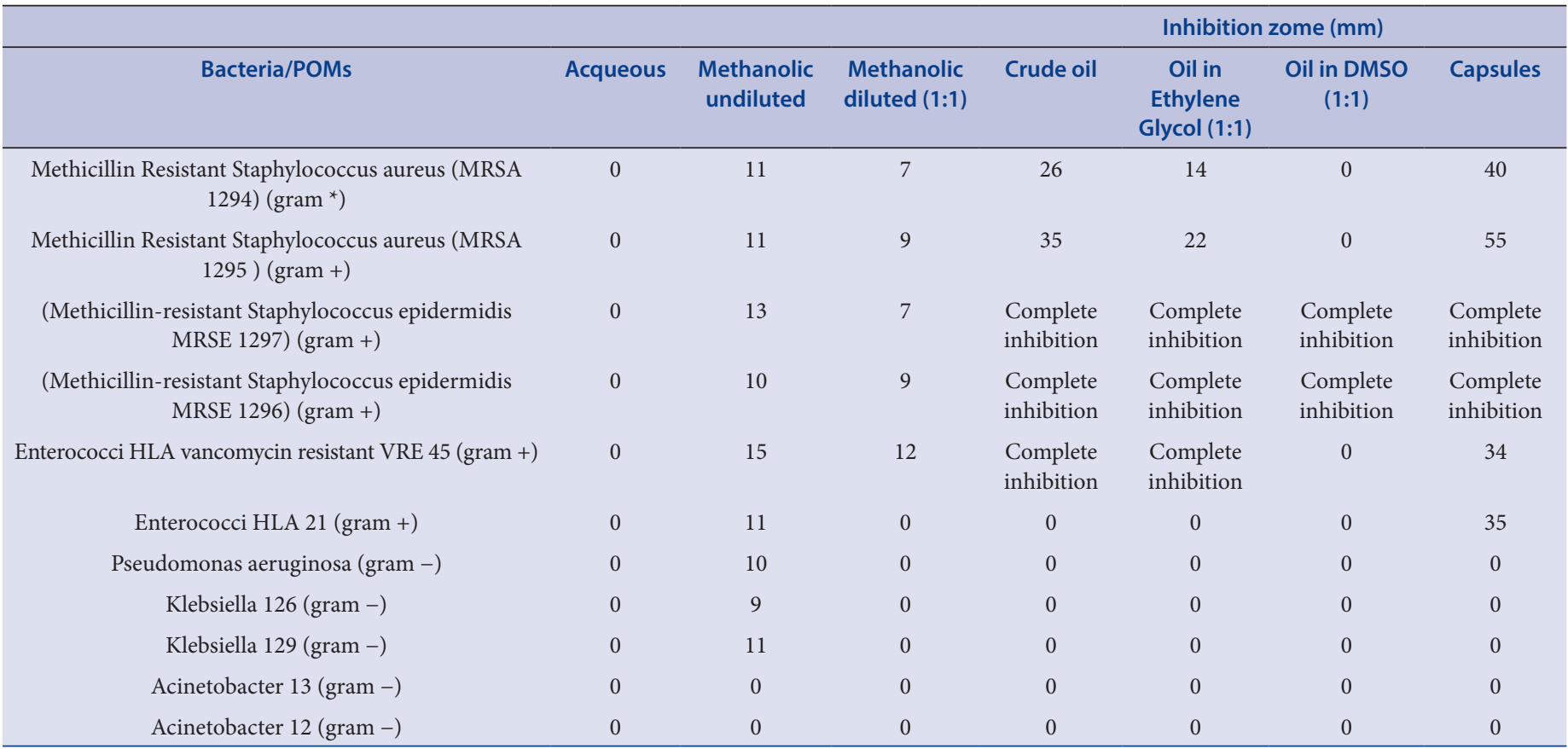

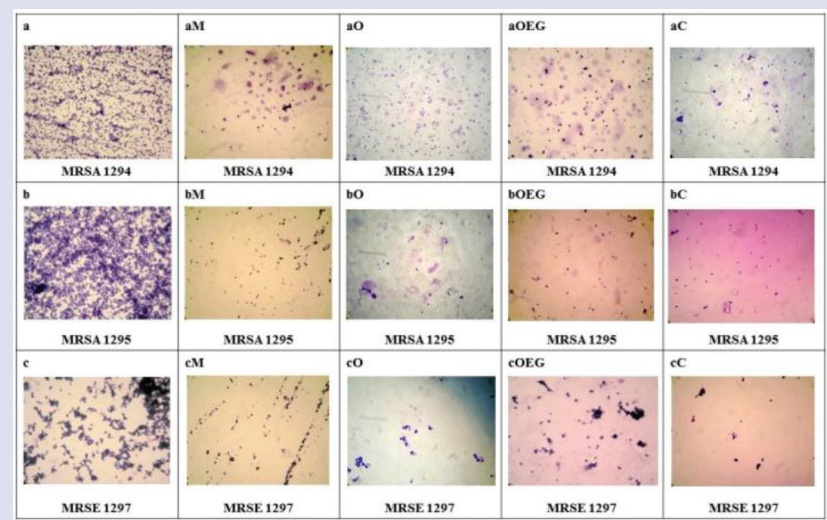

Figure 3: Microscopic visualization of the effect of Nigella sativa preparations ( $M$ for Methanolic extract; $O$ for crude oil, $E G$ for oil diluted in Ethylene Glycol, and C for Capsules) on three biofilm positive strains MRSA 1294, MRSA 1295 and MRSE 1297 cultured on glass slides covers.

phenolic and flavonoid components at alcoholic concentration of $500 \mathrm{mg} / \mathrm{ml}$. The extracts diluted in methanol showed as well an antibacterial activity but lower than in pure methanol. The crude oil and the diluted ones showed an antibacterial activity. However, the crude oil demonstrated better results than the diluted one. Capsules showed the best effect with the highest inhibition zone suggesting that the antibacterial efficacy of $N$. sativa preparations is associated with their high bioactive contents. Those results are is in good agreement with previous studies by, ${ }^{33} \backslash \mathrm{u} 03 \mathrm{~b} 1$-thujene $(5.6 \%$ reporting that the essential oils like thymoquinone are responsible for the strong antimicrobial activity of $N$. sativa oil ${ }^{33} \backslash \mathrm{u} 03 \mathrm{~b} 1$-thujene (5.6\%. However, there is increasing amount of evidence that the activity of $N$. sativa oils may not rely exclusively on the main active components present, but also on the interactions between those components and other constituents in the oil.

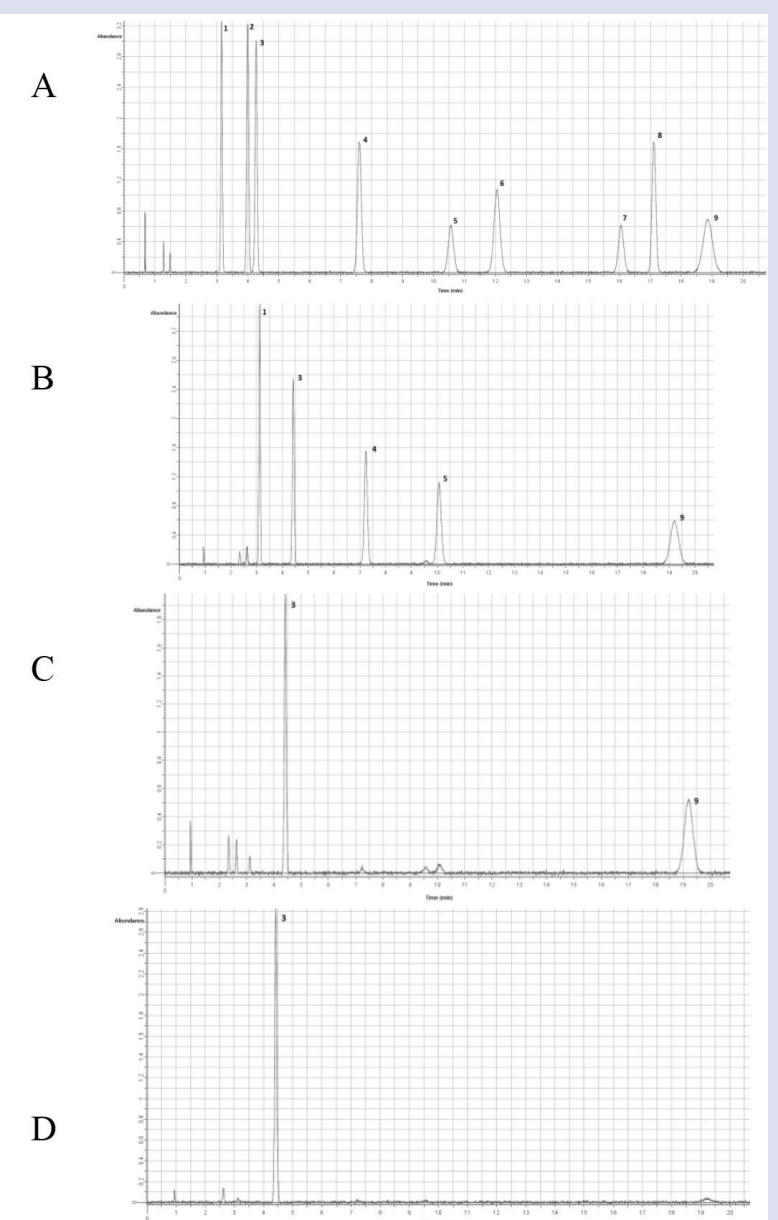

Figure 4: GC-MS analysis of Nigella sativa preparations:(A) Oil (B) Capsule (C) Methanolic extract (D) Aqueous extract. 


\begin{tabular}{|c|c|c|c|c|c|c|}
\hline $\mathbf{N}$ & Compound & RT & Oil & $\begin{array}{c}\text { Capsule } \\
(\%)\end{array}$ & $\begin{array}{l}\text { Methanolic } \\
\text { extract (\%) }\end{array}$ & $\begin{array}{c}\text { Aqueous } \\
\text { extract (K) }\end{array}$ \\
\hline 1 & Beta-Pinene & 3.1 & 9.1 & 10.0 & - & - \\
\hline 2 & O-Cymene & 4.0 & 8.7 & - & - & - \\
\hline 3 & Thymoquinone & 4.3 & 7.8 & 8.6 & 37 & - \\
\hline 4 & Palmitic acid & 7.6 & 5.0 & 5.6 & - & - \\
\hline s & Oleic acid & 10.2 & 7.2 & 8.1 & - & - \\
\hline 6 & Linoleic acid & 12.1 & 9.5 & - & - & - \\
\hline 7 & 9.12-Octadecadieneoic acid (Z-Z)-, methyl ester & 16.1 & 7.1 & - & - & - \\
\hline 8 & 1-Heptatriacotanol & 17.2 & 6.9 & - & - & - \\
\hline 9 & Thymol & 18.9 & 9.4 & 10.3 & 6.4 & _ \\
\hline
\end{tabular}

\section{Effect of Nigella sativa extracts on biofilm formation on glass microscope slide covers}

$N$. sativa preparations were tested for their potential to prevent biofilm formation of three gram-positive resistant bacterial stains (MRSA 1294, MRSA 1295 and MRSE 1297). Prevention of biofilm formation by methanolic extracts, crude oil, oil diluted in EG and capsule content was shown by microscopic visualization. $N$. sativa preparations reduced the biofilm formation of all bacterial strains tested compared to the positive controls (non-treated bacteria, Figure 3a, b, c). A moderate biofilm formation reduction was noted for the methanolic extracts and oil diluted in EG. Whereas, the highest suppression of biofilm formation was observed for crude oil and capsule content. Our results are in accordance with the study of ${ }^{21}$ who showed that thymoquinone, an active principle of $N$. sativa is able to prevent bacterial biofilm formation. Toconfirm this, we performed GC-MS analysis of the different preparations.

\section{GC-MS Analysis}

N. sativa oil GC-chromatogram has shown the presence of 9 major peaks (Figure 4A), and the components corresponding to the peaks have been determined: Beta-Pinene (9.1\%), O-Cymene (8.7\%), Thymoquinone (7.8\%), Palmitic acid (5.0\%), Oleic acid (7.2\%), Linoleic acid (9.5\%), 9,12-Octadecadieneoic acid (Z-Z)-, methyl ester (7.1\%), 1-Heptatriacotanol (6.9\%), and Thymol (9.4\%) (Table 2). Moreover, N. sativa capsule GC-chromatogram has shown the presence of 5 major peaks (Figure 4B), and the components corresponding to the peaks have been determined: Beta-Pinene (10.0\%), Thymoquinone (8.6\%), Palmitic acid (5.6\%), Oleic acid (8.1\%), and Thymol (10.3\%) (Table 2). Furthermore, N. sativa methanolic extract GC-chromatogram has shown the presence of 2 major peaks (Figure 4C), and the components corresponding to the peaks have been determined: Thymoquinone (3.7\%) and Thymol (6.4\%) (Table 2). Nevertheless, $N$. sativa aqueous extract GC-chromatogram has shown the presence of one major peak, Thymoquinone (6.9\%) (Table 2). As shown in Table II, Thymoquinone is the common bioactive component of all $N$. sativa preparations, which is in agreement with the literature ${ }^{34}$ and Beta-Pinene is the major constituent of $N$. sativa oil. Our results are quite different from the work of ${ }^{35}$ who reported that p-cymene $(37.3 \%)$ and thymoquinone $(13.7 \%)$ were the major components of $N$. sativa oil. ${ }^{36}$ also reported that $N$. sativa oil contains $p$-cymene as the major component. Our results show that the oil and the capsule contain considerable amounts of bioactive compounds (Beta-Pinene, Thymoquinone, thymol and Oleic acid). However, these compounds were absent in N. sativa methanolic and aqueous extracts, and hence the antiradical and antimicrobial activities of the oil and capsule could be attributed to the complex interactions between the individual components.

\section{CONCLUSION}

In this work, we proposed the use of $N$. sativa preparations as a potential source for antiradical and antibacterial activities. All N. sativa preparations have shown the ability to act as antioxidants by free radical inhibition, with the oil and capsules content showing the higher activity. $N$. sativa was also assessed for its antibacterial activity against highly resistant gram-positive and gram-negative bacteria. Generally, all preparations were strongly active against bacterial growth and biofilm formation for gram-positive bacteria. $N$. sativa capsule and oil were found to present the highest antibacterial activity, mainly attributed to their rich bioactive components. Therefore, N. sativa preparations can be suggested as a useful alternative for some infectious diseases, such as a decolonizing agent for gram-positive bacteria if it is incorporated in a local ointment as well as natural preservatives in food industry.

\section{ACKNOWLEDGEMENT}

The authors would like to thank Mrs. G. Onsy for proof reading the manuscript.

\section{CONFLICTS OF INTEREST}

The authors wish to confirm that there are no known conflicts of interest associated with this publication and there has been no significant financial support for this work that could have influenced its outcome.

\section{ABBREVIATION USED}

MDR: Multidrug resistant; GC-MS: Gas chromatographic-mass spectrometric; MICs: The minimal inhibitory concentrations; ESBL: extended-spectrum $\beta$-lactamases; Ye: Total phenolic content; DPPH: 1,1-diphenyl-2-picrylhydrazyl); BHT: Butylhydroxytoluene; CE: Catechin equivalent; EG: Ethylene glycol.

\section{REFERENCES}

1. Boneca IG, Chiosis G. Vancomycin resistance: occurrence, mechanisms and strategies to combat it. Expert Opin Ther Targets. 2003;7(3):311-28. doi:10.1517/14728222.7.3.311.

2. Lewis K, Ausubel FM. Prospects for plant-derived antibacterials. Nature Biotechnology. 2006;24(12):1504-7. doi:10.1038/nbt1206-1504.

3. Lai PK, Roy J. Antimicrobial and chemopreventive properties of herbs and spices. Current Medicinal Chemistry. 2004;11(11):1451-60 doi:10.2174/0929867043365107.

4. Mazid M, Khan TA, Mohammad F. Role of secondary metabolites in defense mechanisms of plants. Biology and Medicine. 2011;3(2):232-49. doi:citeulikearticle-id:10435815

5. Witkowska AM, Hickey DK, Alonso-Gomez M, Wilkinson M. Evaluation of antimicrobial activities of commercial herb and spice extracts against selected food-borne bacteria. Journal of Food Research. 2013;2(4):37-54. doi:10.5539/ 
jfr.v2n4p37.

6. Goreja WG. Black seed. Nature's Miracle, Remedy Amazing Herbs Press, New York. 2003:1-64

7. Gad AM, El-Dakhakhny M, Hassan MM. Studies on the chemical constitution of Egyptian Nigella sativa L. oil. Planta Medica. 1963;11(2):134-8.

8. Ali BH, Blunden G. Pharmacological and toxicological properties of Nigella sativa. Phytotherapy Research. 2003;17(4):299-305. doi:10.1002/ptr.1309.

9. Al-Ghamdi MS. The anti-inflammatory, analgesic and antipyretic activity of Nigella sativa. Journal of Ethnopharmacology. 2001;76(1):45-8. doi:10.1016/S03788741(01)00216-1.

10. Khan MA, Chen HC, Tania M, Zhang DZ. Anticancer activities of Nigella sativa (Black Cumin). African Journal of Traditional, Complementary and Alternative Medicines. 2011;8(5):226-32. doi:10.4314/ajtcam.v8i5S.10.

11. Kanter M, Coskun $\mathrm{O}$, Uysal $\mathrm{H}$. The antioxidative and antihistaminic effect of Nigella sativa and its major constituent, thymoquinone on ethanol-induced gastric mucosal damage. Archives of Toxicology. 2006;80(4):217-24. doi:10.1007/ s00204-005-0037-1.

12. Hanafy MSM, Hatem ME. Studies on the antimicrobial activity of Nigella sativa seed (black cumin). Journal of Ethnopharmacology. 1991;34(2-3):275-8. doi:10.1016/0378-8741(91)90047-H.

13. Ugur AR, Dagi HT, Ozturk B, Tekin G, Findik D. Assessment of In vitro Antibacterial Activity and Cytotoxicity Effect of Nigella sativa Oil. Pharmacognosy Magazine. 2016;12(Suppl 4):S471-S4. doi:10.4103/0973-1296.191459.

14. Mariod AA, Ibrahim RM, Ismail M, Ismail N. Antioxidant activity and phenolic content of phenolic rich fractions obtained from black cumin (Nigella sativa) seedcake. Food Chemistry. 2009;116(1):306-12. doi:10.1016/j.foodchem. 2009.02.051.

15. Farag MA, Gad HA, Heiss AG, Wessjohann LA. Metabolomics driven analysis of six Nigella species seeds via UPLC-qTOF-MS and GC-MS coupled to chemometrics. Food Chemistry. 2014;151:333-42. doi:10.1016/j.foodchem.2013.11.032.

16. Singleton VL, Orthofer R, Lamuela-Raventós RM. [14] Analysis of total phenols and other oxidation substrates and antioxidants by means of folin-ciocalteu reagent. Methods in Enzymology. 1999;299:152-78.

17. Ribéreau-Gayon P, Dubourdieu D, Donèche B, Lonvaud A. Traité d'CEnologie. Tome 1: Microbiologie du Vin, Vinifications. Dunod, Paris. 1998.

18. Brand-Williams W, Cuvelier M-E, Berset C. Use of a free radical method to evaluate antioxidant activity. LWT-Food Science and Technology. 1995;28(1):25-30.

19. ZHANG S, ZHAO L. Advance in Researches on Extraction and Purification of the Flavonoid Compounds [J]. Journal of Wenzhou University (Natural Sciences). 2007;5:5.

20. CLSI. Performance standards for antimicrobial susceptibility testing; TwentyFourth Informational Supplement. Clinical and Laboratory Standards Institute. 2014;34(1):M100-S23.

21. Chaieb K, Kouidhi B, Jrah H, Mahdouani K, Bakhrouf A. Antibacterial activity of Thymoquinone, an active principle of Nigella sativa and its potency to prevent bacterial biofilm formation. BMC complementary and alternative medicine. 2011;11(1):29. doi:10.1186/1472-6882-11-29.

22. Sarwar A, Latif Z. GC-MS characterisation and antibacterial activity evaluation of Nigella sativa oil against diverse strains of Salmonella. Natural Product Research. 2015;29(5):447-51. doi:10.1080/14786419.2014.947493.

23. Cheikh-Rouhou S, Besbes S, Hentati B, Blecker C, Deroanne C, Attia H.
Nigella sativa L.: Chemical composition and physicochemical characteristics of lipid fraction. Food Chemistry. 2007;101(2):673-81. doi:10.1016/j.foodchem. 2006.02.022.

24. PeschelW, Dieckmann W, Sonnenschein M, Plescher A. High antioxidant potential of pressing residues from evening primrose in comparison to other oilseed cakes and plant antioxidants. Industrial Crops and Products. 2007;25(1):44-54. doi:10.1016/j.indcrop.2006.07.002.

25. Bourgou S, Ksouri R, Bellila A, Skandrani I, Falleh H, Marzouk B. Phenolic composition and biological activities of Tunisian Nigella sativa L. shoots and roots. Comptes Rendus - Biologies. 2008;331(1):48-55. doi:10.1016/j.crvi.2007.11.001.

26. Rajha HN, Louka N, Darra N El, et al. Multiple Response Optimization of High Temperature, Low Time Aqueous Extraction Process of Phenolic Compounds from Grape Byproducts. Food and Nutrition Sciences. 2014;5(4):351-60. doi:10.4236/fns.2014.54042.

27. Rajha HN, Darra N El, Vorobiev E, Louka N, Maroun RG. An Environment Friendly, Low-Cost Extraction Process of Phenolic Compounds from Grape Byproducts Optimization by Multi-Response Surface Methodology. Food and Nutrition Sciences. 2013;2013(June):650-9. doi:10.4236/fns.2013.46084.

28. Rajha HN, El Darra N, Hobaika Z, et al. Extraction of total phenolic compounds, flavonoids, anthocyanins and tannins from grape byproducts by response surface methodology. Influence of solid-liquid ratio, particle size, time, temperature and solvent mixtures on the optimization process. Food and Nutrition Sciences. 2014;5(4):397.

29. Moreno S, Scheyer T, Romano CS, Vojnov A a. Antioxidant and antimicrobial activities of rosemary extracts linked to their polyphenol composition. Free Radical Research. 2006;40(2):223-31. doi:10.1080/10715760500473834.

30. Naz S, Ahmad S, Ajaz Rasool S, Asad Sayeed S, Siddiqi R. Antibacterial activity directed isolation of compounds from Onosma hispidum. Microbiological Research. 2006;161(1):43-8. doi:10.1016/j.micres.2005.05.001.

31. Russell AD. Biocide use and antibiotic resistance: The relevance of laboratory findings to clinical and environmental situations. Lancet Infectious Diseases. 2003;3(12):794-803. doi:10.1016/S1473-3099(03)00833-8.

32. Zarai Z, Boujelbene E, Ben Salem N, GargouriY, Sayari A. Antioxidant and antimicrobial activities of various solvent extracts, piperine and piperic acid from Piper nigrum. LWT - Food Science and Technology. 2013;50(2):634-41. doi:10.1016/j. Iwt.2012.07.036

33. Singh S, Das SS, Singh G, Schuff C, de Lampasona MP, Catalán C a N. Composition, in vitro antioxidant and antimicrobial activities of essential oil and oleoresins obtained from black cumin seeds (Nigella sativa L.). BioMed Research International. 2014;2014:918209. doi:10.1155/2014/918209.

34. Burits M, Bucar F. Antioxidant activity of Nigella sativa essential oil. Phytotherapy Research. 2000;14(5):323-8. doi:10.1002/1099-1573(200008)14:5<323::AIDPTR621>3.0.CO;2-O.

35. Hajhashemi V, Ghannadi A, Jafarabadi H. Black Cumin Seed Essential Oil, as a Potent Analgesic and Antiinflammatory Drug. Phytotherapy Research. 2004;18(3):195-9. doi:10.1002/ptr.1390.

36. Singh G, Marimuthu P, De Heluani CS, Catalan C. Chemical constituents and antimicrobial and antioxidant potentials of essential oil and acetone extract of Nigella sativa seeds. Journal of the Science of Food and Agriculture. 2005;85(13):2297-306. doi:10.1002/jsfa.2255.

\section{GRAPHICAL ABSTRACT}

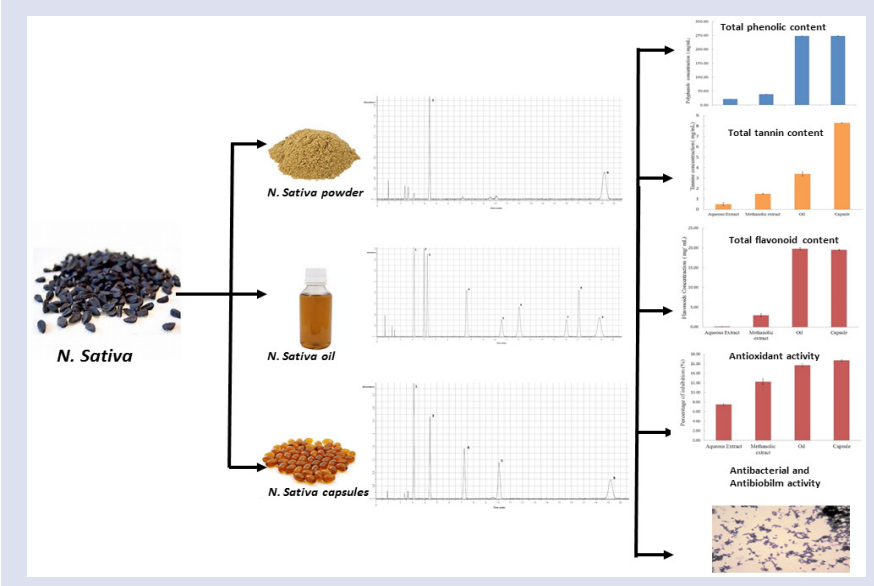

\section{SUMMARY}

- In this study, total phenolic content, tannin, and flavonoid content of $N$. sativa seed extracts and its commercially available oil were determined. Their radical scavenging activity using DPPH method was also tested. The antibacterial activity of $N$. sativa seed extracts and its oil against different multidrug resistant gram-positive and gram-negative bacterial strains was studied using disc diffusion test and the biofilm formation assay. Gas chromatographic-mass spectrometric studies were also performed to describe the essential oil and fixed oil (fatty acid) composition of the different $N$. sativa preparations. 


\section{ABOUT AUTHORS}

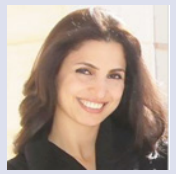

Dr. Fatima A. Saleh: I obtained my BSc in Pharmacy with honors from Beirut Arab University, Lebanon in 2004. I earned my M.Sc. in Pharmacology and Biotechnology from Sheffield Hallam University, UK in 2005, then worked as a researcher at the Biomedical Tissue Research Group, University of York, UK. I was subsequently awarded a BBSRC CASE scholarship to pursue my PhD in biological sciences at University of York, UK. After completing my PhD in 2011, I worked as a research associate at Hull York Medical School (HYMS), UK. I have a number of publications in peer-reviewed journals. In 2013, I returned to Lebanon to be appointed as an assistant professor at Medical Laboratory Technology department, Faculty of Health sciences, at Beirut Arab University.

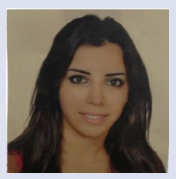

Dr. Nada El Darra: I obtained my BSc in Life and Earth Sciences from Saint-Joseph University, Lebanon in 2007. I earned my M.Sc. in Food chemistry with honors from Saint-Joseph University, Lebanon in 2009. Then worked as a Quality manager at Conserves Modernes Chtaura_Lebanon. In 2013, I obtained a certificate entitled "ISO 22000:2005" Food safety management System Lead Auditor from RABOSA. I was subsequently awarded a scholarship to pursue my PhD under a joint program between Saint-Joseph University and University of Technology of Compiègne_France. I obtained in 2013 a PhD in Food chemistry from Saint-Joseph University and a PhD in Industrial Process Engineering and Sustainable Development from University of Technology of Compiègne France. After completing my PhD, i worked in 2014 as a Quality manager at Abido Spices_Neemeh_Lebanon. I have a number of publications in peer-reviewed journals. In 2014, I was appointed as an assistant professor at Nutrition \& Dietetics department, Faculty of Health sciences, at Beirut Arab University.

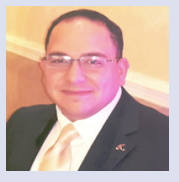

Dr. Karim M. Raafat: Is an Associate Professor of Phytochemistry and Pharmacognosy at Faculty of Pharmacy, Beirut Arab University. He has completed his PhD from German University in Cairo, New Cairo, Egypt, under the channel system and joint supervision scheme between The German University in Cairo (GUC) and Johann Wolfgang Goethe-University Frankfurt, Germany and postdoctoral studies from Beirut Arab University (BAU) and German University in Cairo. He is a visiting Scientist of Johann Wolfgang Goethe-University, Frankfurt, Germany. He is the Head of Phytochemistry Research Team and Junior Research Team, BAU, Lebanon. He has published more than fifty books, patent, and peer reviewed journal articles and presentations in scientific conferences. He has been honored with several national and international awards in the scientific field and public service.

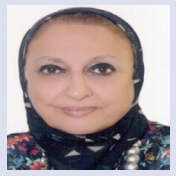

Prof. Iman El Ghazzawy: I obtained my Bachelor of Medicine (MBBCH) from Alexandria University in 1976. Then my MSc from the same university in 1980. In 1986, I earned my PhD, Faculty of Medicine- Alexandria University. I have been teaching from 1992 till end of 2015 in Alexandria University, Egypt. I have been also a visiting professor for eight times at the Faculty of Medicine, Beirut Arab University from 1998 till 2015 as well as Gryounis university at Benghazi, Libya for two successive academic years 2005-2006 for postgraduate medical students. In 2015-2016, I was assigned as the Head of Medical Laboratory Technology Department, Faculty of Health Science at Beirut Arab University.

Cite this article: Saleh FA, El-Darra N, Raafat K, El-Ghazzawi I. Phytochemical analysis of Nigella sativa L. Utilizing GC-MS exploring its antimicrobial effects against multidrug-resistant bacteria. Pharmacog J. 2018;10(1):99-105. 